\title{
Penggunaan Media Buku Cerita Bergambar untuk Meningkatkan Kemampuan Bahasa Anak Kelompok B RA Riyadlul Jannah Wrati Kejayan Pasuruan
}

\author{
Siti Nurkhaula ${ }^{1}$, Yuli Ani Setyo Dewi ${ }^{2}$ \\ ${ }^{12}$ STITNU Al-Hikmah Mojokerto \\ chula.elrizky@gmail.com \\ yulianisetyo85@gmail.com
}

\begin{abstract}
Abstrak: Berdasarkan studi pendahuluan yang telah dilakukan, penelitian ini di latar belakangi oleh rendahnya kemampuan membaca anak. Hal ini terbukti dari antusias anak tidak nampak, anak cenderung kurang percaya diri ketika kegiatan belajar mengajar. Latar belakang ini, masalah yang ingin dipecahkan pada penelitian ini apakah media buku cerita bergambar dapat meningkatkan kemampuan bahasa pada anak kelompok B RA Riyadlul Jannah Wrati Kejayan Pasuruan. Adapun tujuan dari penelitian ini yaitu untuk menemukan terjadinya peningkatan kemampuan bahasa dengan media buku cerita bergambar di RA Riyadlul Jannah Wrati Kejayan Pasuruan. Buku-buku bergambar dimaksudkan untuk mendorong ke arah apresiasi dan kecintaan terhadap buku.

Jenis penelitian ini adalah penelitian tindakan kelas (PTK) dengan menggunakan 2 siklus dan pelaksanaannya 2 bulan. Disetiap siklus terdiri dari perencanaan, pelaksanaan, observasi dan refleksi. Subjek penelitiannya adalah anak kelompok B RA Riyadlul Jannah Wrati Kejayan Pasuruan yang berjumlah 14 anak, yaitu terdiri dari 5 anak perempuan dan 9 anak laki-laki. Adapun teknik pengumpulan data yang dilakukan dalam penelitian ini adalah melalui observasi dan dokumentasi. Teknik analisis data menggunakan statistik deskriptif.

Berdasarkan hasil kemampuan membaca anak dengan menggunakan media buku cerita bergambar pada siklus 1 pertemuan 1 diperoleh data $62,35 \%$, pada siklus 1 pertemuan 2 diperoleh hasil 63,3\%. Target pencapaian dari penelitian ini adalah $75 \%$. Maka berdasarkan data pada siklus 1 baik pertemuan 1 dan 2 belum mencapai $75 \%$. Oleh sebab itu, penelitian ini berlanjut pada siklus 2 . Selanjutnya pada siklus 2 pertemuan 1 diperoleh $83,3 \%$ dan pada siklus 2 pertemuan 2 mencapai $85,5 \%$. Berdasarkan analisis pada siklus 2 maka nilai yang diharapkan telah tercapai. Peneliti dapat menyimpulkan bahwa penggunaan buku cerita bergambar dapat meningkatkan kemampuan bahasa anak kelompok B RA Riyadlul Jannah Wrati Kejayan Pasuruan.
\end{abstract}

Kata Kunci: Media, Buku Cerita Bergambar, Kemampuan Bahasa 


\section{PENDAHULUAN}

Raudhatul Athfal merupakan salah satu bentuk pendidikan prasekolah yang ada dijalur pendidikan sekolah. Pendidikan prasekolah adalah pendidikan untuk membantu pertumbuhan dan perkembangan, jasmani dan rohani anak di luar lingkungan keluarga sebelum memasuki pendidikan dasar. Adapun yang menjadi tujuan program kegiatan belajar anak Raudhatul Athfal adalah untuk membantu meletakkan dasar ke arah perkembangan sikap, pengetahuan, keterampilan, dan daya cipta yang diperlukan oleh anak didik dalam menyesuaikan diri dengan lingkungannya dan untuk pertumbuhan dan perkembangan selanjutnya. Masa anak-anak adalah masa bermain, oleh sebab itu kegiatan pendidikan di Raudhatul Athfal diberikan melalui bermain sambil belajar dan belajar sambil bermain.

Kemampuan berbahasa anak merupakan suatu hal yang penting karena dengan bahasa tersebut anak dapat berkomunikasi dengan teman atau orang-orang di sekitarnya. Bahasa merupakan bentuk utama dalam mengekspresikan pikiran dan pengetahuan bila anak mengadakan hubungan dengan orang lain. Bahasa juga suatu simbol atau lambang yang digunakan untuk menyampaikan keinginan/pikiran dan berkomunikasi dengan orang lain baik berupa verbal maupun visual (Dewi, 2017a). Anak yang sedang tumbuh dan berkembang mengkomunikasikan kebutuhan, pikiran dan perasaannya melalui bahasa dengan kata-kata yang mempunyai makna.

Pengembangan berbahasa mempunyai empat komponen yang terdiri dari pemahaman, pengembangan perbendaharaan kata, penyusunan kata-kata menjadi 
kalimat dan ucapan (Dahlan dalam Daroah,2013 : 3) Keempat pengembangan tersebut memiliki hubungan yang sangat terkait satu sama lain, yang merupakan satu kesatuan. Keempat keterampilan tersebut perlu dilatih pada anak usia dini karena dengan kemampuan berbahasa tersebut anak akan belajar berkomunikasi dengan orang lain, sebagaimana dalam kurikulum 2004 diungkapkan bahwa kompetensi dasar dari pengembangan bahasa untuk anak usia dini yaitu anak mampu mendengar, berkomunikasi secara lisan, memilikiperbendaharaan kata dan mengenal simbol-simbol yang melambangkannya.

Hasil dari penelitian yang dilakukan oleh (Dewi, 2014) menunjukkann bahwa salah satu penghambat guru dalam pembelajaran adalah kurangnya media pembelajaran yang dimiliki oleh sekolah. Begitu juga dalam upaya untuk meningkatkan keterampilan bahasa anak, guru harus dapat menerapkan beberapa media pembelajaran. Salah satu media pembelajaran bahasa yang digunakan dalam penelitian ini terutama dalam keterampilan bercerita adalah buku cerita bergambar. Media gambar adalah media yang paling umum dipakai. Sadiman (2011: 29) mengartikan media gambar sebagai bahasa yang umum, yang dapat dimengerti dan dapat dinikmati dimana-mana.

Kemampuan berbahasa anak pada kelompok B RA Riyadlul Jannah Wrati Kejayan Pasuruan belum sesuai dengan yang diharapkan yaitu merangkai kata menjadi kalimat, bercerita, dan perbendaharaan kosa kata. Anak mengalami kesulitan dalam merangkai suku kata menjadi kata, merangkai kata menjadi kalimat, mengingat kosakata yang baru, bercerita dengan kalimat sederhana secara urut. Hal ini dimungkinkan karena kegiatan belajar mengajar di RA Riyadlul 
Jannah Wrati Kejayan Pasuruan masih bersifat konvensional walaupun sudah banyak tersedia media pembelajaran inovatif sehingga anak merasa bosan dan tidak mudah berkonsentrasi. Untuk itu perlu strategi dalam mengolah media pembelajaran melalui model pembelajaran dengan aktivitas bahasa, dengan demikian diharapkan anak dapat lebih mudah menerima materi pembelajaran dengan perasaan senang, tanpa paksaan dan tidak melanggar prinsip dari psikologi perkembangan anak. Dari hasil penelitian yang telah dilakukan (Dewi, 2017b) banyak stimulasi yang digunakan oleh para guru agar perkembangan bahasa siswanya bisa berkembang secara maksimal yaitu diantaranya mengajak mereka berdialog dan berkomunikasi baik di dalam maupun di luar kelas.

Pada dasarnya anak usia 5 - 6 tahun lebih mudah mempelajari hal-hal yang bersifat konkrit baru kemudian bersifat abstrak, karenanya penggunaan media pembelajaran dan keikutsertaan anak secara langsung dalam setiap kegiatan untuk pengembangan kemampuan berbahasanya sangat berperan penting. Dengan penggunaan media pembelajaran dan keikutsertaan atau keterlibatan anak dalam aktifitas untuk memahami bahasa baik secara konkret (menulis) maupun abstrak (merangkai suku kata menjadi kata, merangkai kata menjadi kalimat) menjadi stimulan yang dapat memudahkan anak untuk mengembangkan kemampuan bahasanya. 


\section{METODE PENELITIAN}

\section{Rancangan Penelitian}

Penelitian ini merupakan Penelitian Tindakan Kelas (PTK), karena penelitian ini dilakukan untuk memecahkan masalah pembelajaran di dalam kelas yang di dalamnya berusaha mengkaji beberapa aspek kegiatan belajar-mengajar, seperti keterlaksanaan rencana pembelajaran dan kemampuan bahasa anak. Dalam Penelitian ini menggunakan pendekatan deskriptif kualitatif dan kuantitatif dengan subjek penelitian hanya satu kelas, dengan pembelajaran menggunakan Media Buku Cerita Bergambar. Peneliti ingin mendeskripsikan penerapan pembelajaran menggunakan Media Buku Cerita Bergambar yang dapat meningkatkan Kemampuan Bahasa Anak.

Dalam melakasanakan Penelitian Tindakan Kelas, sejumlah kegiatan dilaksanakan secara berulang-ulang mulai dari tahapan perencanaan, pelaksanaan, dan refleksi merupakan serangkaian kegiatan yang utuh yang membentuk suatu siklus. Setiap siklus terdiri atas 4 tahapan (Arikunto, 2010:16), yaitu: (a) Perencanaan (Planning), (b) Pelaksanaan (Acting), (c) Pengamatan (Observing), (d) Refleksi (Reflecting)

\section{Perencanaan}

Dalam tahap perencanaan ini peneliti melakukan 5 kegiatan utama, yaitu: meneliti kelas, menentukan tindakan, membuat RPPH dan Alat peraga, Menyusun Instrumen Penelitian, Membuat lembar observasi

Meneliti Kelas 
Dalam tahap perencanaan ini peneliti melakukan studi awal dengan melakukan tindakan refleksi terhadap kondisi yang ada ditempat penelitian di laksanakan. Dalam hal ini tempat penelitian di RA Riyadlul Jannah pada Kelompok B. Pada kegiatan berguna untuk mengidentifikasi, mengevaluasi masalah yang akan di teliti ini.

\section{Menentukan Tindakan}

Setelah meneliti kelas dengan melakukan studi awal terhadap situasi dan kondisi kelas, kemudian merencanakan langkah-langkah yang harus dilakukan bersama-sama kolaborator untuk meneliti peningkatan kemampuan membaca anak dengan menggunakan media buku cerita bergambar. Dalam kegiatan menentukan tindakan ini susunan Perencanaan yang sistematis agar memudahkan peneliti dalam pelaksanaan tindakan dengan menggunakan siklus dilakukan sebanyak $2 \mathrm{x}$.

Membuat RPPH dan Alat Peraga

Pada kegiatan ini merencanakan penyusunan langkah-langkah pembelajaran dengan menyiapkan Rencana Pelaksanaan Pembelajaran Harian (RPPH) bersama kolaborator. Dalam skenario pembelajaran di RPPH terdapat kegiatan pembeljaran, metode, alat peraga, penilaian, format observasi pembelajaran.

Menyusun Instrumen Penelitian

Dalam pelaksanaan tindakan nantinya disertai observasi sehingga harus mempergunakan instrumen. Instrumen observasi PTK ini memuat indikator yang diharapkan dapat menggambarkan keberhasilan dan kekurangan keseluruhan 
tindakan dalam penggunaan buku cerita bergambar dalam meningkatkan kemampuan bahasa anak sebagai bahan refleksi guru.

Menyusun Lembar observasi

Lembar observasi yang dirancang dalam perencanaan ini terdapat 2 lembar kegiatan observasi yaitu lembar observasi guru yang akan diisi oleh kolaborator yang bertugas sebagai pengamat dan juga lembar observasi anak untuk mengetahui tingkat keberhasilan dan kekurangan dari tahap tindakan selanjutnya untuk bahan refleksi.

\section{Tindakan}

Tindakan dalam penelitian tindakan kelas mencakup prosedur dan tindakan yang akan dilakukan, serta proses perbaikan yang akan dilakukan.

\section{Observasi}

Pada proses observasi atau pengamatan dilakukan pada saat proses pembelajaran berlangsung. Guru atau kolaborator yang bertindak sebagai observer untuk melakukan pengamatan dan pencatatan perkembangan-perkembangan dan kegiatan yang terjadi saat proses pembelajaran dan berfokus pada format yang tersedia. Observasi ini dilaksanakan agar memperoleh data yang akurat untuk melanjutkan ke siklus selanjutnya dan untuk mengetahui sejauh mana keberhasilan yang dicapai oleh guru atau peneliti dalam pembelajarannya.

\section{Refleksi}

Refleksi menguraikan tentang prosedur analisis terhadap hasil pengamatan dan refleksi tentang proses dan dampak tindakan perbaikan yang dilakukakan, serta kriteria dan rencana tindakan pada siklus selanjutnya. 


\section{Populasi}

Populasi dalam penelitian ini adalah anak kelompok B RA Riyadlul Jannah Desa Wrati Kecamatan Kejayan Kabupaten Pasuruan sebanyak 14 anak, terdiri dari 9 laki-laki dan 5 perempuan

\section{Variabel Penelitian}

\section{Jenis Variabel}

Secara umum dinyatakan bahwa variabel adalah proyek penelitian atau apa yang menjadi titik perhatian suatu penelitian. Adapun yang menjadi variabel data judul penelitian ini adalah :

\section{Variabel Bebas}

Variabel bebas adalah variabel yang berpengaruh atau yang menyebabkan berubahnya variabel terikat dan merupakan variabel yang diutamakan dalam penelitian. Variabel bebas dalam penelitian ini adalah buku cerita bergambar.

Variabel Terikat

Variabel terikat adalah gejala yang muncul atau berubah dalam pola yang teratur dan bisa diamati atau berubah variabel lainnya (Arikunto, 2006:119). Yang menjadi variabel terikat dalam penelitian ini adalah kemampuan bahasa.

\section{Sumber Data}


Yang dimaksud dengan sumber data adalah subjek dimana data dapat diperoleh (Arikunto, 2006:120). Dalam penelitian ini sumber data yang digunakan adalah semua anak dikelompok B RA Riyadlul Jannah Wrati Kejayan Pasuruan.

\section{Instrumen Penelitian}

Menurut Arikunto (2007:101) Instrumen penelitian adalah alat bantu yang dipilih dan digunakan oleh peneliti dalam kegiatannya mengumpulkan data agar kegiatan tersebut menjadi sistematis dan dipermudah olehnya. Dalam penyusunan instrumen penelitian adalah pertama menetapkan variabel-variabel penelitian. Dari variabel-variabel yang akan diteliti tersebut kemudian ditentukan indikator yang diukur dan indikator-indikator ini dijabarkan menjadi butir-butir pernyataan dan pertanyaan. Guna memudahkan penyusunan instrumen penelitian, maka diperlukan kisi-kisi instrumen penelitian. Kisi-kisi instrumen penelitian dalam teknik observasi sebagai berikut: 1) Lembar observasi aktivitas anak, 2) Lembar observasi aktifitas guru, 3) Lembar hasil kemampuan anak, 4) Skala bertingkat (Rating Scale )

\section{Teknik Pengumpulan Data}

Dalam penelitian ini data menjadi hal yang sangat penting, terutama apabila peneliti menggunakan metode-metode yang memiliki cukup besar celah untuk memasuki unsur minat peneliti. Dalam penelitian ini peneliti menyimpulkan data dengan menggunakan metode observasi.

\section{Analisa Data}


Teknik analisa data adalah cara yang digunakan untuk mengolah dan menganalisis data-data yang diperoleh tersebut, sehingga data yang ada dapat dianalisa secara statistik untuk dapat membuktikan kebenaran dari data yang telah dikumpulkan. Adapun langkah-langkah dalam analisa data adalah sebagai berikut: 1. Editing (pengeditan), 2. Coding (pengkodean), 3. Tabulating (data dalam bentuk tabel)

\section{Pengujian Hipotesis}

Selanjutnya adalah perhitungan terhadap hasil skor yang telah ada. Karena penelitian ini adalah untuk melihat apakah ada korelasi antara buku cerita bergambar dengan kemampuan bahasa anak, maka yang dipakai adalah Korelasi Product Moments atau Product Moment Correlation yang lengkapnya Product of the Moment Correlation adalah salah satu teknik untuk mencari korelasi itu sering dikenal dengan istilah teknik korelasi antar dua variabel. Teknik ini dikembangkan oleh Karl Pearson. Karena itu sering kali dikenal dengan istilah teknik korelasi pearson.

Korelasi product moment ini merupakan koefisien korelasi yang diperoleh dengan cara mencari hasil perkalian dari moment-moment variabel yang dikorelasikan. Dalam penggunaan analisa data ini penulis menggunakan metode pengumpulan data seperti tersebut di atas. dalam analisa data penulis menggunakan teknik analisa data statistic korelasi Product Moment dengan rumus sebagai berikut:

Rumus : P = F X 100\% ( Sudjiono, 2010:43)

N Keterangan : 
$\mathrm{P}=$ Prosentase hasil perolehan

$\mathrm{F}=$ Jumlah Skor perolehan

$\mathrm{N}=$ Jumlah skor Maksimal

\section{A. Indikator Ketercapaian Tindakan}

Pada indikator pencapaian tindakan dari penelitian ini pihak peneliti atau partner memberi check $(\sqrt{ })$ sesuai dengan hasil pelaksanaan penelitian di lapangan. Untuk mengetahui menganalisis ketuntasan atau keberhasilan penelitian yang dilakukan, sebagai Rumus :

Berikut kriteria untuk menganalisa ketuntasan belajar anak dalam pembelajaran kemampuan bahasa melalui media buku cerita bergambar:

1. $\quad 0 \%-25 \%=$ Belum Berkembang $(\mathrm{BM})$

2. $26 \%-50 \%=$ Mulai Berkembang $(\mathrm{MM})$

3. $51 \%-5 \%=$ Berkembang Sesuai Harapan $(\mathrm{BSH})$

4. $\quad 76 \%-100 \%=$ Berkembang Sangat Baik $(\mathrm{BSB})$

Dari hasil penelitian yang diperoleh dilapangan diharapkan peneliti adanya peningkatan kemampuan bahasa anak dengan media buku cerita bergambar. Menurut Djamarah (2006:107) mengatakan standar keberhasilan belajar mengajar bisa dianggap mencapai "Tuntas" adalah setelah mendapatkan prosentase skor $\geq$ 75\%. Menurut ahli diatas dapat dinyatakan bahwa peningkatan kemampuan belajar anak terutama peningkatan kemampuan bahasa melalui media buku cerita bergambar dapat dinyatakan berhasil atau "Tuntas" bila mendapatkan prosentase skor $\geq 80 \%$. 


\section{HASIL}

Dalam hal ini akan dijelaskan tentang kegiatan yang dilakukan peneliti untuk menjawab permasalahan yang telah disebutkan di atas. Proses penelitian guru mendapatkan hasil penelitian ini mencakup beberapa tahapan sebagai berikut:

\section{Tahap Persiapan}

Sebelum peneliti melakukan penelitian kelapangan untuk mengumpulkan data, peneliti mempersiapkan hal-hal sebagai berikut: 1) Penentuan Masalah dan Judul Penelitian, 2) Pelaksanaan Studi Pendahuluan, 3) Penyusunan proposal Penelitian dan Ijin Penelitian

\section{Tahap Pelaksanaan}

Penelitian Tindakan Kelas (PTK) tentang meningkatkan kemampuan bahasa anak usia dini melalui media buku cerita bergambar kelompok B RA Riyadlul Jannah Desa Wrati Kecamatan Kejayan Kabupaten Pasuruan dengan subyek penelitian sebanyak 14 anak yang telah dilaksanakan melalui 2 siklus dengan hasil penelitian sebagai berikut:

\section{Siklus I Pertemuan I dan Pertemuan II}

\section{Penyusunan Rencana Tindakan}

Dalam siklus I pertemuan I dilaksanakan penyusunan Rencana Pelaksanaan Pembelajaran (RPPH) yang akan digunakan dalam pembelajaran disesuaikan dengan tema yang ada. Siklus I pertemuan I ini dilaksanakan pada hari senin, 5 februari 2018. Indikator yang ingin dicapai yaitu kemampuan mengenal dan mengerti semua huruf dan bentuk-bentuknya, dapat 
menghubungkan antara kalimat dan gambar, mengenal kosakata baru berikut gambarannya, dapat membedakan dan membuat kata dari suku kata awal dan suku kata akhir, dapat membaca kata-kata yang terdiri dari dua, tiga atau empat buku cerita bergambar. Selain itu peneliti mempersiapkan alat observasi yang akan digunakan dalam mengamati kegiatan pembelajaran dari kegiatan awal sampai akhir yang dilakukan guru dalam melaksanakan pembelajaran.

\section{Pelaksanaan Tindakan}

Pada tahap ini, kegiatan yang dilakukan adalah melaksanakan tindakan sesuai dengan rencana pembelajaran yang telah disusun. Adapun urutan kegiatan secara garis besar adalah sebagai berikut: 1) Kegiatan Awal, 2) Kegiatan Inti, 3) Kegiatan Akhir

\section{Hasil Observasi}

Hasil pengamatan yang dilakukan peneliti dalam mengamati kegiatan anak dan guru yang digunakan dalam proses pembelajaran dengan instrument yang ada.

Adapun pengolah data hasil observasi aktivitas anak, aktivitas guru dan hasil belajar anak adalah sebagai berikut:

\section{Observasi Aktivitas Anak}

Aktivitas anak dalam kegiatan bercerita menunjukkan persentase pertemuan I , 54\%, ini berarti anak belum termotivasi dan belum mencapai target seperti yang diharapkan.

Observasi Aktivitas Guru 
Pengamatan terhadap guru dilakukan oleh teman sejawat pada saat proses kegiatan bercerita dan menghasilkan pertemuan I, 58,3\%.

\section{Refleksi}

Berdasarkan pengamatan peneliti pada pembelajaran kegiatan bercerita untuk meningkatkan kemampuan membaca anak usia dini pada siklus I pertemuan I merefleksikan sebagai berikut:

Pada saat awal siklus I, pelaksanaan belum sesuai dengan rencana. Hal ini disebabkan karena : 1) Sebagian anak belum banyak beraktivitas sesuai dengan yang diharapkan, 2) Sebagian anak belum dapat berkonsentrasi dan perhatian secara utuh dan menyeluruh, 3) Anak masih belum tertarik untuk mengikuti kegiatan bercerita beberapa anak yang memerlukan motivasi dalam kegiatan, 4) Dari pengamatan teman sejawat, guru dalam menyampaikan materi bercerita masih belum dapat memotivasi anak untuk mendengarkan cerita. Cerita yang disampaikan oleh guru terlalu cepat. Intonasi, mimik dan suara yang disampaikan guru monoton sehingga kurang melibatkan konsentrasi dan perhatian anak, hanya anak tertentu saja yang dapat mengikuti dengan baik.

Dari hasil diskusi dan refleksi maka peneliti bersama kolabolator merencanakan pembelajaran ada pertemuan selanjutnya dengan memperbaiki kelemahan yang ada pada pertemuan I yaitu mengajak anak agar terlibat secara aktif dalam pembelajaran. Peranan guru dalam menyampaikan cerita tidak terlalu cepat dan hendaknya cerita disampaikan dengan ekspresi dan intonasi sesuai 
dengan alur cerita. Rendahnya persentase ketuntasan dari ketetapan yang dikehendaki atau belum memenuhi target yang ditetapkan yaitu minimal 75\% anak menguasai materi maka dilanjutkan pertemuan II.

Siklus II Pertemuan I dan Pertemuan II Penyusunan Rencana Tindakan Dalam siklus II pertemuan I dan II dilaksanakan penyusunan Rencana Pelaksanaan Pembelajran Harian (RPPH) yang akan digunakan dalam pembelajaran disesuaikan dengan tema yang ada. Siklus II pertemuan I ini dilaksanakan pada hari Senin, 12 Februari 2018. Indikator yang ingin dicapai yaitu kemampuan mengenal dan mengerti semua huruf dan bentuk-bentuknya, dapat menghubungkan antara kalimat dan gambar, mengenal kosakata baru berikut gambarannya, dapat membedakan dan membuat kata dari suku kata awal dan suku kata akhir, dapat membaca kata-kata yang terdiri dari dua, tiga atau empat buku cerita bergambar. Selain itu peneliti mempersiapkan alat observasi yang akan digunakan dalam mengamati kegiatan pembelajaran dari kegiatan awal sampai akhir yang dilakukan guru dalam melaksanakan pembelajaran. Pelaksanaan Tindakan Pelaksanaan kegiatan pembelajaran untuk siklus II dilaksanakan pada tanggal 12 Februari 2018 dikelompok B dengan jumlah anak 14 anak. Dalam penelitian ini, peneliti bertindak sebagai observer. Adapun proses pembelajaran pada skenario pembelajaran yang termuat dalam rencana pelaksanaan pembelajaran yang telah disiapkan sebelumnya. Pelaksanaan tindakan ini adalah proses pembelajaran yang dilakukan guru dari awal hingga akhir dengan langkah-langkah pembelajaran sebagai berikut: 1) Kegiatan Awal, 2) Kegiatan Inti, 3) Kegiatan Akhir. 


\section{Hasil Observasi}

Observasi Aktivitas Anak Aktivitas anak dalam kegiatan membaca buku cerita bergambar menunjukkan pada pertemuan II meningkat menjadi 83,3\% ini berarti anak sudah termotivasi dan sudah mencapai target seperti yang diharapkan Observasi Aktivitas Guru Pengamatan terhadap guru dilakukan oleh teman sejawat pada saat proses kegiatan bercerita pertemuan II meningkat memperoleh persentase $87,5 \%$

\section{PEMBAHASAN}

Dari hasil pengolahan dan analisis data baik dari pengamatan yang dilakukan siklus I dan siklus II secara keseluruhan telah disampaikan bahwa telah terjadi perubahan yang sangat positif. Hal ini dapat diamati dari hasil analisis pada siklus I, yaitu hasil analisis observasi guru 58,3\%, hasil analisis observasi anak sekitar 54\% dan hasil peningkatan kemampuan membaca sebesar 41,17\% dikarenakan banyak kekurangan diawal pembelajaran sehingga anak belum menikmati. Sedangkan pada siklus II dapat diamati suatu peningkatan terjadi pada hasil analisis observasi guru sebesar $87,5 \%$ dan pada hasil analisis observasi anak sebesar $83,3 \%$ serta untuk hasil peningkatan kemampuan membaca sebesar 82,35\%. Peningkatan yang cukup signifikan ini dikarenakan kekurangan pada siklus I diperbaharui dan guru menggunakan strategi baru yaitu bukan gambar 
dahulu namun huruf dahulu hingga anak belajar kosakata lebih memahami dan menyenangkan.

Dari paparan penjelasan diatas maka dapat disimpulkan bahwa buku cerita bergambar mampu meningkatkan kemampuan bahasa anak di RA Riyadlul Jannah Wrati Kejayan Pasuruan. Dapat dilihat pada diagram ini bahwa terjadi peningkatan yang cukup signifikan pada penggunaan media buku cerita bergambar.

\section{KESIMPULAN}

Dari hasil penelitian yang telah diuraikan pada bab sebelumnya yang terkait dengan penelitian meningkatkan kemampuan membaca anak melalui media buku cerita bergambar di kelompok B RA Riyadlul Jannah Wrati Kejayan Pasuruan, dapat disimpulkan bahwa penelitian yang telah dilakukan selama 2 bulan telah diperoleh hasil penelitian yang cukup memuaskan, yaitu bahwa media buku cerita bergambar dapat meningkatkan kemampuan membaca anak TK kelompok B. Hal ini terbukti dari hasil penelitian yang telah dilakukan terjadi peningkatan secara signifikan dari sebelum tindakan sampai siklus II, yaitu : (1) pada observasi guru siklus I 58,3\% menjadi $87,5 \%$ pada siklus II, (2) observasi anak siklua I 54\% menjadi $83,3 \%$ pada siklus II, dan (3) Pada hasil meningkatnya kemampuan membaca anak siklus I senilai $41,17 \%$ menjadi $82,35 \%$ pada siklus II.

\section{DAFTAR PUSTAKA}

Futicha-turisqoh.blogspot.co.id. www.makalahskripsi.com/2010. 
Aqib, Zainal, dkk. 2009.Penelitian Tindakan Kelas. Bandung : Yrama Widya. https://gitamediapembelajaran.wordpress.com.

Nur Khalimi, Muhammad.2013.Penerapan Metode Circle Of Learning Untuk Meningkatkan Hasil Belajar Siswa.Pasuruan: Pustaka Al-Yasini.

Aisyah, Siti. 2007.Pembelajaran Terpadu. Jakarta: Departemen Pendidikan Nasional.

Ali, Mohamad. 1984. Penelitian Kependidikan. Bandung : Angkasa.

Dhinie, Nurbian, dkk. 2005. Metode Pengembangan Bahasa. Jakarta: Departemen Pendidikan Nasional.

Dewi, Y. A. S. (2014). Analisis Implementasi Kurikulum Tingkat Satuan Pendidikan (KTSP) di Sekolah Dasar Negeri Pisang Candi 1 Malang. Modeling, 1(2), 94-109.

Dewi, Y. A. S. (2017a). Korelasi Efektivitas Komunikasi dan Latar Belakang Etnis/Suku Orangtua Terhadap Perkembangan Bahasa Anak di Raudlatul Athfal Kabupaten Pasuruan. Seling, 3(1), 99-114.

Dewi, Y. A. S. (2017b). Metode Pembelajaran Guru Etnis Jawa- Madura Dalam Pengembangan Bahasa Siswa RA di Kabupaten Pasuruan. Seling, 3(2), 94 106.

Hildayani, Rini, dkk. 2005. Psikologi Perkembangan Anak. Jakarta: Departemen Pendidikan Nasional.

Nazir, Moh. 1988. Metode Penelitian. Jakarta: Ghalia Indonesia.

Asrori, H Mohammad,.Psikologi Pembelajaran. Bandung:CV. Wacana Prima, 2008

Winatoputra; Udin S. (2008). Teori Belajar dan Pembelajaran. Jakarta: Universitas Terbuka 